\title{
Peninjauan Partisipasi Politik Bagi Perempuan Pada Pemilu 2019 di Kecamatan Meureubo
}

\author{
Rahma Hidayati ${ }^{1}$ Fiandy Mauliansyah ${ }^{2}$ \\ 1,2Jurusan Ilmu Komunikasi, Universitas Teuku Umar \\ Email: rahmahidayati@utu.ac.id \\ Email: Fiandymauliansyah@gmail.com
}

Submitted: 05 Desember 2019 Revised: 24 Desember 2019 Accepted: 30 Desember 2019

\begin{abstract}
This article wants to see how the participation of women in Meureubo sub-district in welcoming the democratic party during the election of legislative candidates in April 2019. As is known, the involvement of women in politics is still very low. The method used is the Lecture method and then discusses with women representatives from several villages in the Meureubo sub-district. The results show that some of them chose women legislative candidates due to various reasons, namely only women who understood about women so that there was a need for women's representation in parliament, women rarely tripped over corruption cases, women were not equal to men. But for those who do not vote for women legislative candidates due to reasons, namely women are not fit to be leaders, the election of women candidates is only for fulfillment of the quota so that party choices are less than optimal, women are less capable of politics. However, in the end they only hoped that the representation of women or men in the legislature could help empower other women, especially from Meurebo sub-district.
\end{abstract}

Keywords: Political Participation, Women, Elections

\begin{abstract}
Abstrak
Artikel ini ingin melihat bagaimana partisipasi perempuan yang ada di Kecamatan Meureubo dalam menyambut pesta demokrasi pada pemilihan calon legislatif pada April 2019 yang lalu. Sebagaimana diketahui keterlibatan perempuan dalam hal politik masih sangat rendah. Metode yang dilakukan adalah metode Ceramah kemudian berdiskusi dengan para perempuan perwakilan dari beberapa desa yang ada di kecamatan meureubo. Hasil menujukkan bahwa sebagian mereka memilih calon legislatif perempuan disebabkan berbagai alasan yaitu hanya perempuan yang mengerti tentang perempuan sehingga perlu adanya keterwakilan perempuan di parlemen, perempuan jarang tersandung kasus korupsi, perempuan tidak searogan laki-laki. Namun bagi mereka yang tidak memilih calon legislatif perempuan disebabkan oleh alasan yaitu wanita tidak layak jadi pemimpin, pemilihan caleg perempuan hanya untuk pemenuhan kuota saja sehingga pilihan partai kurang maksimal, perempuan kurang mampu berpolitik. Namun pada akhirnya mereka hanya berharap dengan adanya keterwakilan perempuan ataupun laki-laki dalam legislatif dapat membantu memberdayakan para perempuan yang lain khususnya dari Kecamatan Meureubo.
\end{abstract}

Kata Kunci: Partisipasi Politik, Perempuan, Pemilu

\section{PENDAHULUAN}

Pemilihan Umum (Pemilu) 17 April 2019 telah disambut oleh masyarakat Indonesia sebagai pesta demokrasi lima tahun sekali. Pasca reformasi di tahun 1998, demokrasi di Indonesia tumbuh semakin dewasa. Hal ini dapat dilihat ketika pada tahun 2004, untuk pertama kalinya bangsa Indonesia melakukan Pemilihan Presiden secara langsung. Masyarakat bebas 
memilih calon yang terbaik menurut mereka. Pun pada pemilu 2019 lalu.

Undang-Undang No. 10 Tahun 2008 tentang Pemilihan Umum Anggota DPR, DPD, dan DPRD (UU Pemilu Legislatif) telah mengakomodasi tindakan afirmatif bagi perempuan. Di antaranya adalah ketentuan yang mengharuskan daftar calon legislatif yang menentukan peraturan minimal harus ada 30 persen perempuan (Rubaidah, 2018).

Meureubo adalah kecamatan yang berada di Kabupaten Aceh Barat, Provinsi Aceh, Indonesia. Luas kecamatan mencapai 112, 87 $\mathrm{Km}^{2}$ yang terdiri dari 2 mukim dan 26 desa atau gampong. Persentase terhadap luas kabupaten 3,85\%. Ibukota kecamatan berada di Meureubo. Adapun daftar desa yang termasuk kedalam kecamatan ini adalah sebagai berikut: Mukim Meureubo terdiri dari beberapa desa yaitu: Bukit Jaya, Balee, Gunong Kleng, Langung, Meureubo, Paya Peunaga, Peunaga Cut Ujong, Peunaga Pasi, Peunaga Rayeuk, Pucok Reudeup, Sumber Batu, Ujong Drien, Ujong Tanjong. Sedangkan Mukim Ranto Panjang terdiri dari desa: Masjid Tuha, Buloh, Pasi Aceh Baroh, Pasi Aceh Tunong, Pasi Mesjid, Pasi Pinang, Paya Baro Ranto Panyang, Pulo Tengoh Ranto Panyang, Ranto
Payang Barat, Ranto Payang Timur, Ranup Dong, Ujong Tanoh Darat (Wikipedia, 2018).

Adapun batas-batas Kecamatan:

1. Sebelah Utara : Kecamatan Pante Ceureumen

2. Sebelah Selatan : Samudera Indonesia

3. Sebelah Barat : Kecamatan Johan Pahlawan

4. Sebelah Timur: Kabupaten Nagan Raya

Jika dilihat wacana perbincangan mengenai keterlibatan perempuan dalam ranah politik merupakan permasalahan yang masih menjadi isu utama di berbagai belahan dunia. Pada negara-negara yang sistem demokrasinya telah mapan sekalipun, persoalan perempuan dan politik selalu menjadi topik penting dalam setiap penyelenggaraan pemilihan umum, termasuk di Indonesia.

Ada beberapa alasan mengapa perempuan harus berkiprah di politik salah satunya adalah untuk melindungi hak-hak mereka yang selama ini terabaikan. Banyak nya kasus-kasus yang terjadi seperti catatan Komnas Perempuan pada tahun 2018 sebanyak 348.446 kasus kekerasan yang dialami perempuan, pelanggaran hak anak 4.885 kasus (KPAI, 2018). Masih ada eksploitasi terhadap perempuan di tempat kerja, pelanggaran hak cuti haid, 
pelanggaran hak menyusui, dan hak bayi, yang belum sepenuhnya direalisasikan. Selain itu masih terjadi diskriminasi regulasi terhadap batas usia perkawinan untuk perempuan terkait usia relatif muda yakni 16 tahun (UU Nomor 1 Tahun 1974 tentang Perkawinan), dan adanya perlakuan tidak adil terhadap perempuan pekerja migran. "Negara, khususnya melalui lembaga legislatif belum serius menyikapi persoalan yang kerap dihadapi perempuan dan anak (Antara \& Kurniawati, 2019). Apa alasan mereka memilih calon legislatif dan apa pula alasan mereka tidak memilih caleg perempuan.

Menurut Gaffar dalam Efriza (2012) pemilu adalah sarana utama mewujudkan demokrasi dalam suatu negara. Substansi pemilu adalah penyampaian suara rakyat untuk membentuk lembaga perwakilan dan pemerintahan sebagai penyelenggara negara. Suara rakyat diwujudkan dalam bentuk hak pilih, yaitu hak untuk memilih wakil dari berbagai calon yang ada.

Indonesia telah menyelenggarakan Pemilu sejak 1955. Jika dilihat sebelumnya ke belakang, pengalaman pelaksanaan pemilu atau sistem perwakilan telah terlaksana sejak jaman koloni. Pemilu telah terlaksana secara berturut-turut pada tahun, 1971, 1977, 1982, 1987, 1992 dan 1997. Pemilu berikutnya seharusnya diadakan tahun 2002, namun karena kondisi politik, sosial dan krisis ekonomi yang berlarut saat itu maka pada tahun 1998 yang akhirnya meruntuhkan dominasi rejim Soeharto, maka Pemilu diadakan tahun 1999 dan Indonesia menjadi negara yang berhasil mengadakan pemilu paling demokratis sejak 30 tahun (Saifullah Ma'shum, 2001).

Pada awalnya hanya ada satu kategori pemilu yaitu pemilu untuk memilih anggota DPR dan DPRD. Sesuai dengan (Undang-Undang No. 22 Tahun 2007) Berikutnya di tahun 2004, sesuai dengan amandemen konstitusi, pemilu dilaksanakan memilih anggota DPR, DPRD Propinsi, DPRD Kabupaten/Kota, anggota DPD, dan pemilu untuk memilih Presiden dan Wakil Presiden. Selain pemilu tersebut, masih ada pemilu yang memilih Gubernur, Bupati, Walikota yang biasa disebut dengan pemilihan kepala daerah atau Pilkada.

Menurut Patrick, elemen penting selama proses pemilu adalah pembentukan kepercayaan rakyat menjelang pemilu (Merloe, 1994). Jika rakyat tidak merasa terlibat secara bebas untuk mengelola pilihan politik, mendapat 
informasi memadai sesuai keperluan dan tujuannya, sebagaimana hak pilihnya dihormati, maka proses pemilu menjadi tidak signifikan. Para kandidat harus mendapat kesempatan yang sama untuk memenangi suara - yaitu pada “tingkat berkompetisi." Lebih jauh, para kandidat juga harus merasakan keterlibatan dalam proses dan menghargai hasil pemilu. Sehingga pemilu menjadi begitu dekat sebagai kegiatan peralihan yang terlaksana sebelum dan sesudah pemilu.

Partisipasi politik (Sitepu, 2012) adalah suatu kegiatan dari warga negara baik secara langsung maupun tidak langsung (tidak sengaja) terkait dengan kebijakankebijakan pemerintah dapat dilakukan oleh individu-individu maupun kelompok secara spontan maupun di mobilisasi. Di sisi lain juga merumuskan bahwa partisipasi politik adalah merupakan kegiatan-kegiatan yang dilakukan oleh individu maupun kelompok untuk ikut serta secara aktif dalam kehidupan politik yakni dengan memilih pimpinan negara baik secara langsung maupun tidak langsung, mempengaruhi kebijakan-kebijakan pemerintah.

Verba, Schlozman dan Brady mengungkapkan bahwa partisipasi merupakan bagian yang sangat menentukan sampai sejauh mana demokrasi mampu memberi dampak terhadap sistem politik pemerintahan. Kebebasan sipil dan politik merupakan faktor yang tidak dapat ditinggalkan dari konstruksi demokrasi (Verba, Schlozman, \& Brady, 1995). Sehingga tiga dimensi utama demokrasi politik mencakupi: persaingan atau kompetisi, partisipasi, kebebasan politik dan sipil (A.Dahl, 2001). Melihat betapa penting partisipasi politik, maka demokrasi akan kehilangan makna apabila keupayaan warganegara untuk berpartisipasi secara bebas dalam proses bernegara itu disekat atau ditiadakan.

Menurut Gatara \& Dzulkiah Partisipasi politik masyarakat timbul secara luas disebabkan oleh beberapa hal: Pertama moderasi yang terjadi dalam semua bidang yang kemudian menyebabkan masyarakat banyak berpartisipasi dalam politik. Kedua Perubahan dalam struktur kelas sehingga timbul persoalan mengenai siapa yang berhak berpartisipasi dalam pembuatan keputusan politik yang mengakibatkan perubahan dalam cara partisipasi politik. ketiga Pengaruh kaum intelektual dan komunikasi massa modern. Ide demokratisasi telah menyebar ke 
negara-negara baru sebelum mereka mengembangkan modernisasi dan industrialisasi secara matang. Keempat Konflik antar kelompok pemimpin politik. Bila timbul konflik antara elit, maka yang dicari adalah rakyat. dan yang terakhir keterlibatan pemerintah dalam urusan sosial, ekonomi, dan kebudayaan. Perkara tersebut seringkali memicu hadirnya tuntutan-tuntutan yang terorganisir untuk ikut serta dalam pembuatan keputusan politik (Gatara \& Moh. Dzulkiah Said, 2007)

Dalam bukunya the Politics of Presence (1998), Ann Philips telah menegaskan bahwa wakil rakyat perempuan di parlemen seharusnya tidak hanya dimaknai dengan jumlah yang banyak tetapi juga dimaknai dengan kehadiran mereka yang memiliki daya transformasi. Maksudnya, kehadiran perempuan anggota legeslatif seyogyanya bermakna secara kuantitatif dan diharapkan mampu membawa ide serta gagasan yang mengubah arah kebijakan politik sehingga pada akhirnya mampu memprestasikan kepentingan konstituennya, yakni kelompok perempuan. Hal inilah yang menjadi subtansi dari politik kehadiran (the politics of presence) ketika memperjuangkan masuknya perempuan dalam parlemen untuk meningkatkantidak hanya partisipasi politik- tetapi juga representasi politik perempuan.

\section{METODE PELAKSANAAN}

Pelaksanaan pengabdian dilakukan di Kecamatan Meureubo pada tanggal 12 April 2019. Kegiatan pengabdian masyarakat ini dilakukan dengan metode ceramah (penulis sebagai narasumber kemudian diikuti oleh para perempuan mewakili dari berbagai desa yang dipilih mewakili dari setiap desa. Setelah ceramah (pemberian materi) selesai maka proses selanjutnya adalah melakukan tanya jawab serta berdiskusi terhadap permasalahan yang terjadi pada saat pemilihan calon legislatif periode 2019-2024. Selanjutnya Jawaban para ibu atas pertanyaan ini dikumpulkan dan didiskusikan lagi sehingga memperoleh kesimpulan dan penyelesaian.

\section{HASIL DAN PEMBAHASAN}

Jika dilihat jumlah kursi yang di duduki oleh perempuan di parlemen tentunya sangat sedikit dibandingkan laki-laki. Termasuk di tingkat Kabupaten Aceh Barat (DPRK). Hal ini menunjukkan bahwa keberpihakan perempuan terhadap caleg perempuan memanglah sangat rendah.

Bentuk-bentuk partisipasi yang dilakukan oleh kaum perempuan 
pada pemilu 2019 tahun ini adalah berupa partisipasi mereka terhadap hak pilih. Pilihan yang mereka tentukan tidak lain bertujuan untuk mewakili aspirasi kelompok perempuan di tingkat legislatif. Namun tidak sedikit dari mereka memilih calon legislatifnya karena ajakan oleh ketua kelompok dari organisasi perempuan. Misalnya adanya kumpulan ketua wirid yasin lalu secara musyawarah dan mufakat mereka memilih salah satu calon yang mereka anggap layak untuk dipilih.

Namun diantara para perempuan ini juga ada beberapa yang tidak mau mengambil kesempatan dalam hal pemilihan disebabkan oleh kekecewaan dengan pilihan sebelumnya namun dalam hal ini selaku pemateri saya sampaikan tidak boleh diam dalam artian tidak memilih (golput) karena satu suara sangat menentukan siapa pemimpin kita yang akan datang karena sampai saat ini masih banyak agenda dan hal penting tentang kepentingan perempuan dan anak yang harus diperjuangkan. Berikut Gambar 1 ketika memberikan materi kepada peserta.

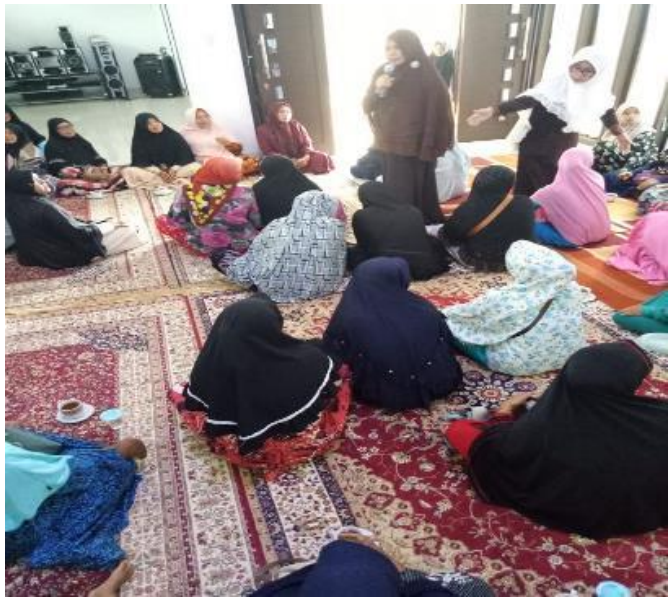

Gambar 1. Memberikan materi kepada peserta

Tidak dapat dipungkiri bahwa perempuan memilih caleg perempuan karena perempuan dianggap manusia yang sulit untuk berbohong dan mampu memahami dan merasakan apa yang dirasakan perempuan pada umumnya, sehingga permasalahan yang menyangkut perempuan hanya perempuanlah yang mengetahuinya.

Mereka juga beranggapan perempuan jarang terlibat kasus korupsi, jujur dalam berbagai hal. Di samping itu banyaknya perempuan yang duduk di parlemen akan berpengaruh pada pengambilan kebijakan yang mengarah pada kondisi lebih baik untuk kepentingan perempuan.

Jika dilihat di media perselisihan pendapat dengan memperlihatkan arogansi yang tidak layak juga banyak diperlihatkan oleh kaum laki-laki. 
Berikut disajikan pada Gambar 2. Sesi tanya jawab dan diskusi dengan peserta.

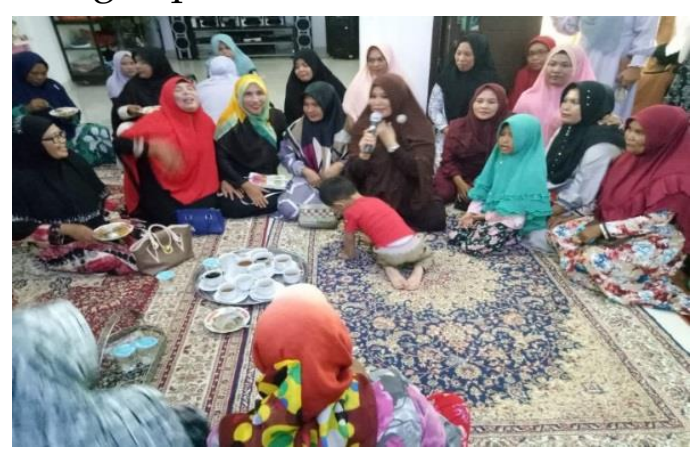

Gambar 2 : sesi tanya jawab dan diskusi dengan peserta

Sebagian masyarakat (dalam hal ini perempuan) memandang bahwa seorang perempuan yang menjadi pemimpin tidak layak karena mendahului kaum laki-laki. Kurangnya kapasitas caleg perempuan yang ikut dalam pemilu juga membuat mereka sulit untuk menentukan pilihan, kecuali calegnya adalah anggota keluarga sehingga tidak mungkin untuk tidak dipilih.

Disisi lain partai politik masih cenderung memilih perempuan calon anggota legislatif secara terburu-buru, terutama demi memenuhi kuota 30 persen. Sehingga mendapatkan calon perempuan yang tidak maksimal.

Pemilihan caleg perempuan biasanya dilatarbelakangi oleh mereka yang mempunyai dukungan massa yang banyak seperti ustazah, bidan desa, guru bahkan dari pengusaha, bukan didasarkan pada kemampuannya dalam berpolitik.

Pada akhirnya para perempuan ini hanya berharap dengan adanya keterwakilan pilihan mereka dalam legislatif dapat membantu memberdayakan para perempuan yang lain khususnya dari Kecamatan Meurebo.

\section{PENUTUP}

Partisipasi politik oleh perempuan yang berada di Kecamatan Meurebo terhadap caleg perempuan dapat dilihat dari dua sisi. Sisi pertama adanya keterlibatan mereka dalam memilih anggota legislatif perempuan. Sisi kedua adanya keterlibatan memilih calon legislatif tetapi bukan dari calon legislatif perempuan. Namun mereka juga berharap keterwakilan mereka baik dari calon legislatif perempuan ataupun laki-laki dapat menampung aspirasi mereka di parlemen.

\section{DAFTAR PUSTAKA}

A.Dahl, R. (2001). Perihal Demokrasi. Jakarta: Yayasan Obor Indonesia.

Antara, \& Kurniawati, E. (2019). Para Perempuan, Perhatikan Hal Berikut Sebelum Memilih Caleg. Retrieved November 19, 2019, from Tempo.co website: https://pemilu.tempo.co/read/ 1167454/para-perempuan- 
perhatikan-hal-berikut-sebelummemilih-caleg/full\&view=ok

Gatara, A. S., \& Moh. Dzulkiah Said. (2007). Sosiologi politik: konse dan dinamika perkembangan kajian. Bandung: CV. Pustaka Setia.

Merloe, P. (1994). Pemilihan Umum Demokrati: Hak Asasi, Kepercayaan Masyarakat dan Persaingan Yang Adil. [Democratic General Election: Human Rights, People's Trust and Fair Competition. Jakarta: Dinas Penerangan Amerika Serikat.

Rubaidah, S. (2018). Keterwakilan Perempuan Dalam Pemilu 2019. Retrieved November 18, 2019, from Berdikari Online website: berdikarionline.com/keterwakil an-perempuan-dalam-pemilu2019/

Saifullah Ma'shum. (2001). KPU $\mathcal{E}$ Kontroversi Pemilu 1999 [General Election Commission and Controversy of the 1999 General Elections]. Jakarta: Pustaka Indonesia Satu.

Verba, S., Schlozman, K. L., \& Brady, H. E. (1995). No Title. USA: Harvard University Press.

Wikipedia, K. (2018). Meureubo, Aceh Barat. https://doi.org/14446462 